excellent, highlighting both the anti-capitalist critique and the text's indebtedness to black power politics and national liberation movements across the globe. Hopefully these efforts will go a long way towards revitalizing a book that Palmer rightly identifies as "arguably one of Canada's most quintessential New Left text[s]" (338). His discussion of Red Power is equally important, as the experiences of Native peoples remain the most understudied aspect of the decade.

Palmer's failure to grant the burgeoning feminist movement more attention than he does is rather disturbing. His discussion of women's consciousness-raising efforts directed against the masculine culture of the New Left occupies a scant ten pages, and his coverage of such important subjects as the Voice of Women is distressingly superficial. It is characteristic of the masculine perspective that haunts this book that the only woman discussed with any kind of depth is Gerda Munsinger, the sexy socialite who was treated as little more than a pretty appendage by her suitors.

The lack of attention to women's issues is troubling, but perhaps in the end is really a reflection of the overtly masculine character of 'the sixties' themselves, and the fact that Canadian women's experiences during this decade remain woefully under-represented in the literature. That said, Palmer would have done well to include a separate chapter on the feminist movement, as he does with the New Left, Québécois radicalism, and Red Power.

As with his other works, Palmer's ultimate message tends at times to become obscured by cumbersome prose and awkward analogies, and the theme of irony is, ironically, underdeveloped throughout the text. Despite these shortcomings, however, as a synthesis of existing works on Canada's 1960s and as an historicisation of our obsessions with national identity, Palmer's latest offering is a most welcome addition to a growing canon of Canadian Sixties lit.

S.D. Jowett

Queen's University

\title{
Sandra Rollings-Magnusson, Heavy Burdens on Small Shoulders: The Labour of Pioneer Children on the Canadian Prairies (Edmonton: University of Alberta Press, 2009).
}

This is a useful little book, accessible to undergraduates in history, sociology, Canadian Studies, and other fields, while providing a handy addition to the libraries of scholars of child labour and family life. Its strength lies in its detailed confirmation of children's work as critical to family survival in the nineteenth and early twentieth century period of prairie farm settlement. Using diaries, letters, memoirs, autobiographies, and other first person accounts, historical sociologist Sandra Rollings-Magnusson draws on the evidence of 260 children, 97 girls and 132 boys, aged from three to their late teens, living in 
Manitoba, Saskatchewan and Alberta (12). She employs a typology to disaggregate their contributions, variously defined as "productive (directed at producing commodities for the market), entrepreneurial (directed to raising funds for the family), subsistence (used to produce goods directly for family consumption), or domestic (directed at family lifestyle, carrying on day-to-day household tasks, and the conversion of subsistence items into consumable form)"(14). This approach, which supplies the basis for core chapters, emphasizes particular values attached to different tasks. The result is some wonderfully thick description that is hard to find elsewhere. I especially enjoyed the fulsome account of the process of building a soddie, or sod house, in the second chapter and of youngsters' efforts to aid family economies, and sometimes their own dreams of pony or rifle ownership, through entrepreneurial initiatives. Children's voices, dreams, and pride emerge ve ry clearly as a marked feature of this volume and justify its publication.

Heavy Burdens also reveals some of shortcomings of its origins as a Phd dissertation in sociology at the University of Alberta and its value is ultimately fairly restricted. Canadian historians familiar with the work of John Bullen, Neil Sutherland, Bettina Bradbury, and Robert McIntosh, not to mention other contributions cited in Labour/Le Travail or this journal over the years, will not find surprises. The centrality of child labour to family survival is now well documented. Feminist scholars in any discipline will also find the recurring comparison to women's undervalued labour pretty slim pickings theoretically and otherwise. Readers of Left History will wonder at the lack of attention to the political economy of the region or at least acknowledgement of the different situations of variously capitalized and situated rural operations. Despite its origins in sociology, Heavy Burdens is barely theorized beyond an acknowledgement of the effects of gender. The typology also underplays the seamlessness of much labour and its frequent fluidity as children's, much like adults', contributions are often simultaneous or shifting from one category to another as needs dictate. Equally problematic is this volume's tendency to ignore difference. The absence of any treatment of race, class, and disability, as of region, is striking and unexpected in 2009. Dependence on a limited pool of written sources has privileged certain memories: namely those of better off settlers and those who have been literate in English. While last names suggest a range of European origins, no other languages (not even French) appear in the cited texts. Equally absent is any discussion of culture. It would be easy to conclude from this volume that all families valued children's labour much the same. While the burdens of farm work might have been heavy, this account suggests that the vast majority were cheerfully demanded by parents and cheerfully borne by offspring. Here then is a good news story of youngsters putting their shoulder to life's wheel and guaranteeing family survival, far from the video-gaming, ADD-afflicted, often obese girls and boys of modern Canada. The fact that "children were almost literally the property of their fathers" (144) gets acknowledged in the conclusion but 
inequalities and oppression of any kind largely go missing here. Neil Sutherland reminded us years ago that survivors of painful childhoods often disappear from view. That is certainly true here. The brutalization of girls and boys by their own families and by their employers that commonly overwhelmed early child welfare efforts on the prairies as elsewhere is nowhere to be found. Ultimately, its reliance on a limited body of sources and inattention to differences of power and experience leaves Heavy Burdens vulnerable to romanticizing the past, even as it recovers details that may well inspire more critical investigations.

Veronica Strong-Boag University of British Columbia

\section{Rusty Bittermann and Margaret McCallum, Lady Landlords of Prince Edward Island: Imperial Dreams and the Defence of Property (Montreal: McGill-Queen's University Press, 2008).}

\section{In Lady Landlords of Prince Edward Island, Rusty Bittermann and Margaret} McCallum show not only female landlords' presence but also their centrality to nineteenth-century Island developments. They argue that women's "attempts to ensure that Island law and policy supported their interests as landlords" made them "significant players" in the project of empire (148). A refreshing approach to Anglo-Canadian imperial history, the study speaks to any scholar interested in gender, Canadian legal and political history, British social history, and experiences of empire and colonialism, broadly speaking.

Lady Landlords aligns with recent trends in British economic history, namely the reconfiguration of traditional economic narratives through a gendered lens. Bittermann and McCallum join a growing contingent of scholars showing that the very nature of economic and legal discourses often obscured female participation. Careful research of provincial documents (detailed in a helpful Appendix) show the extent to which British women featured in Island landholding; women, excluding those sharing property with husbands or family, owned over one quarter of the land held by absentee owners in the 1870s and 1880s.

Bittermann and McCallum organize their work into biographic studies of four such landowners: Anne Saunders, her sister Jane Saunders, Jane's daughter Georgiana Fane, and acquaintance Charlotte Sulivan. Beginning with the Saunders' land inheritance in 1785, the authors plot a rough chronology through the women's lives, which aligned with "most of the history of British imperial involvement with landlordism on Prince Edward Island" (8). This included local anti-landlord resistance of the 1830s, legislative imperatives of the 1850s, and the acquisition of absentee landowners' property by the provincial government in the 1860s and 1870s. The women's lives were so entwined with the Island's political developments, argue the authors, that the 1875 Supreme Court decision striking 